\title{
Izvještaj sa okruglog stola \\ HISTORIJSKI ZNAČAJ PRIJEMA REPUBLIKE BOSNE \\ I HERCEGOVINE U ČLANSTVO ORGANIZACIJE \\ UJEDINJENIH NACIJA - 26 godina poslije, \\ Tuzla, 22. maj 2018. godine
}

U organizaciji Filozofskog fakulteta Univerziteta u Tuzli, Odsjeka za historiju, Arhiva Tuzlanskog kantona, Centra za istraživanje moderne i savremene

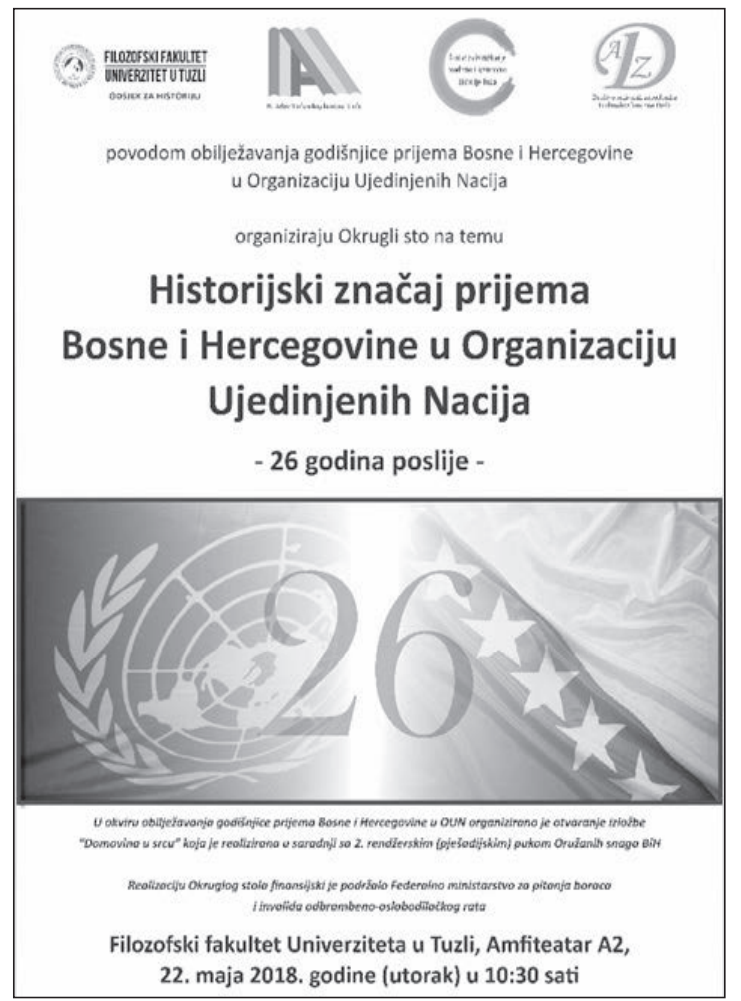

Prilog 1. Plakat okruglog stola "Historijski značaj prijema Bosne i Hercegovine u OUN- $a$ ". historije Tuzla i Društva arhivskih zaposlenika Tuzlanskog kantona 22. maja 2018. godine, sa početkom u 11 sati, u amfiteatru II Filozofskog fakulteta u Tuzli, održan je okrugli sto na temu Historijski značaj prijema Republike Bosne i Hercegovine u članstvo Organizacije Ujedinjenih nacija. Kroz okrugli sto izlagači su podsjetili na okolnosti u kojima je Republika Bosna i Hercegovina postala članica $\mathrm{UN}-\mathrm{a}$, te da i danas nakon 26 godina postoje snage koje ugrožavaju njenu samostalnost i nezavisnost.

U okviru obilježavanja godišnjice prijema Bosne i Hercegovine u Organizaciju Ujedinjenih nacija organizirano je i otvaranje izložbe „Domovina u srcu“, koja je realizirana u saradnji sa 2. pješadijskim (rendžerskim) pukom Oružanih snaga Bosne i Hercegovine. Otvaranju izložbe prisustvovala je i delegacija Oružanih snaga $\mathrm{BiH}$, predvođena kapetanom Almirom Kulugićem.

Status koji danas ima Bosna i Hercegovina prikazan je kroz izložbu Oružanih snaga na 20 panoa o kontinuitetu opstojnosti Bosne i Hercegovine, s 
posebnim isticanjem uloge znamenitih ličnosti koje su kroz različita historijska razdoblja ostavili svoj trag. O samoj izložbi govorio je mr. sc. Omer Zulić. Realizaciju okruglog stola finansijski je podržalo Federalno ministarstvo za pitanja boraca i invalida odbrambeno-oslobodilačkog rata.

U uvodnom dijelu okruglog stola učesnike je pozdravio prof. dr. Sead Selimović, šef Odsjeka za historiju na Filozofskom fakultetu Univerziteta u Tuzli i izvršni direktor Centra za istraživanje moderne i savremene historije Tuzla.

Pred gostima, kolegama i studentima, te učenicima Gimnazije "Meša Selimović" iz Tuzle, šest izlagača dalo je kratak osvrt na značaj 22. maja, dana prijema Bosne i Hercegovine u Organizaciju Ujedinjenih nacija. To su bili:

> Prof. dr. Izet Šabotić (Odsjek za historiju, Filozofski fakultet Univerziteta u Tuzli), Bosna i Hercegovina u procesu disolucije SFRJ,

$>$ Prof. dr. Sead Selimović (Odsjek za historiju, Filozofski fakultet Univerziteta u Tuzli), Doprinos diplomacije Republike Bosne i Hercegovine prijemu u članstvo Ujedinjenih nacija,

> Mr. sc. Omer Zulić (Arhiv Tuzlanskog kantona), Značaj rezolucija UN za Republiku Bosnu i Hercegovinu i odbranu od agresije,

> Mr. Jasmin Jajčević (Centar za istraživanje moderne i savremene historije Tuzla), Ćlanstvo Republike Bosne i Hercegovine u međunarodnim organizacijama 1992-2018,

> Prof. dr. Omer Hamzić (Izdavačka kuća „Monos“, Gračanica, Časopis za kulturnu historiju „Gračanički glasnik“) Bosna i Hercegovina - primjer punopravne članice UN pod „specijalnim tretmanom" svojih susjeda ( $u$ povodu 26. godišnjice članstva Bosne i Hercegovine u UN) $i$

$>$ Mr. Semir Hadžimusić (JU Zavod za zaštitu i korištenje kulturnohistorijskog i prirodnog naslijeđa Tuzlanskog kantona) Prijem Bosne $i$ Hercegovine u članstvo OUN-a - 26 godina poslije.

Moderator okruglog stola bila je dr. sc. Mersiha Imamović sa Filozofskog fakulteta Univerziteta u Tuzli. 


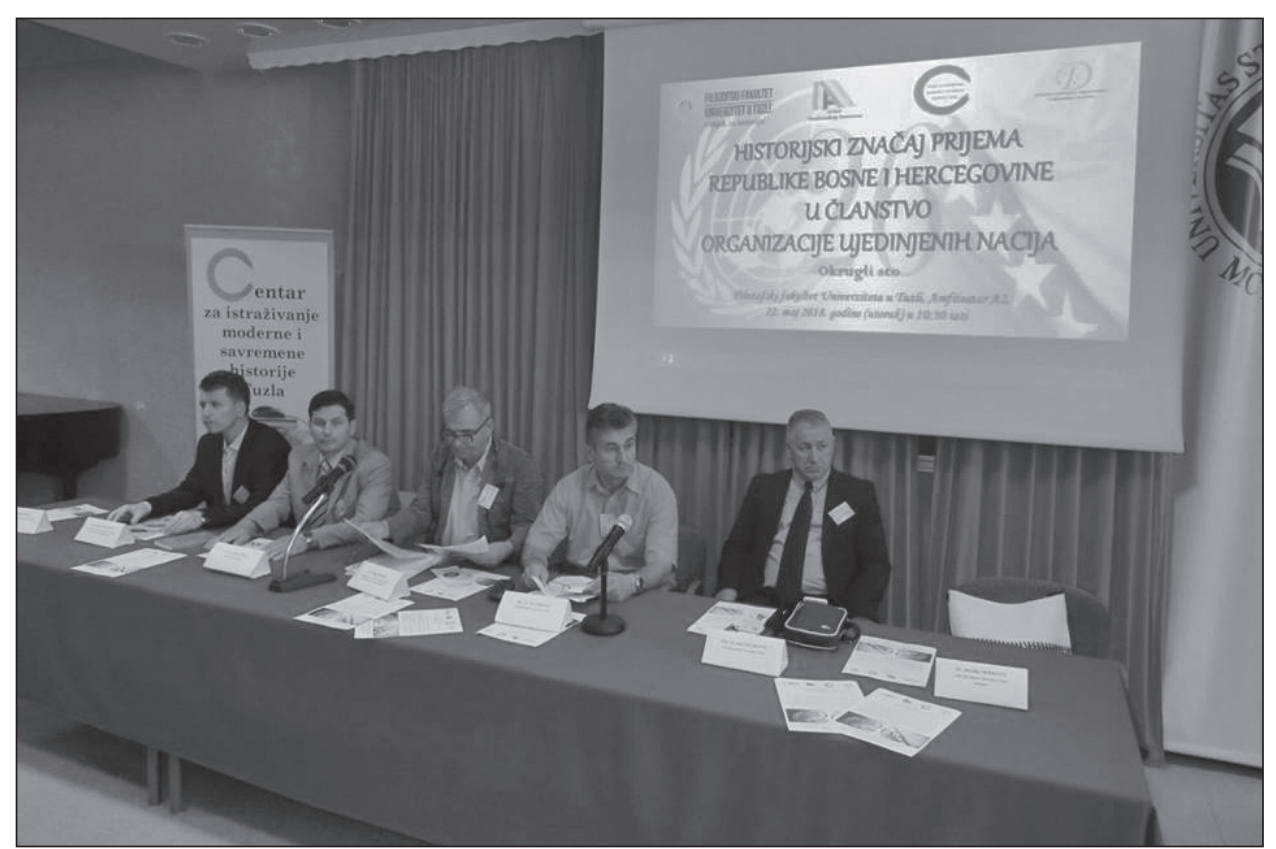

Prilog 2. Učesnici/izlagači na okruglom stolu „Historijski značaj prijema Bosne i Hercegovine u OUN".

Ovim okruglim stolom iznesena su mišljenja i stavovi istaknutih naučnika i univerzitetskih profesora o pitanju prijema Bosne i Hercegovine u UN, te se naglasio značaj obilježavanja datuma, koji su za Bosnu i Hercegovinu od historijskog značaja. U konačnici, svrha održavanja okruglog stola bila je da se ne zaborave važni datumi koji su obilježili historiju Bosne i Hercegovine, a sve u cilju da se podigne svijest široj društvenoj zajednici i posveti značajnija pažnja ovom važnom segmentu historije Bosne i Hercegovine. Opravdanost se ogleda u činjenici da se uz pomoć organiziranja ovakvih okruglih stolova animira šira društvena zajednica, stručna, naučna i kulturna javnost, te razvija svijest kod studenata i građana, odnosno šire društvene zajednice, o značaju obilježavanja historijskih datuma važnih za očuvanje historijske posebnosti Bosne i Hercegovine. Okrugli sto zasigurno je opravdao očekivanja organizatora i učesnika, a za naredni period je najavljena realizacija i drugih sličnih projekata. 